\title{
Investigation of The Effect of Building Material Selection and Design Style on Kiln Thermal Properties in Solar Kilns
}

\author{
Kemal ÜÇÜNCÜ Aytaç AYDIN* \\ Karadeniz Technical University, Department of Forest Industry Engineering Kanuni Campus, Trabzon/Türkiye
}

How to cite: Üçüncü, K. \& Aydın, A. (2020). Investigation of The Effect of Building Material Selection and Design Style on Kiln Thermal Properties in Solar Kilns. J. Anatolian Env. and Anim. Sciences, 5(5), 793-797.

Atıf yapmak için: Ücüncü, K. \& Aydın, A. (2020). Güneş Fırınlarında Yapı Malzemesi Seçimi ve Tasarım Stilinin Fırın Isıl Özelliklerine Etkisinin İncelenmesi. Anadolu Çev. ve Hay. Dergisi, 5(5), 793-797.

(iD): https://orcid.org/0000-0002-6294-6112

* iD : https://orcid.org/0000-0001-7460-9618

*Corresponding author's:

Aytaç AYDIN

Karadeniz Technical University, Department

of Industrial Engineering Kanuni Campus,

Trabzon, Turkey.

$凶:$ aytac@ktu.edu.tr

Mobile telephone: +90 (505) 2319178

Telephone $\quad:+90(462) 3771513$

Fax : +90(462) 3257499

\begin{abstract}
The negative effects of intensive energy consumption in timber drying on costs and environmental pollution have strengthened the tendency to utilize solar energy in recent years. Although drying of timber in flat collector solar furnaces takes more time than conventional drying, energy costs are low and there are no negative environmental effects. In this study, the selection of building materials and design type to be used in the design of solar furnaces was evaluated in terms of thermal properties. Materials with different thermal capacities create different thermal properties in different designs. Therefore, it is possible to control the course of the temperature distribution in the solar timber drying oven throughout the day with the choice of different building materials and design forms.
\end{abstract}

Keywords: Building material, drying, solarkiln, thermalproperties.
*Sorumlu yazarın:

Aytaç AYDIN

Karadeniz Teknik Üniversitesi Orman

Fakültesi Orman Endüstri Mühendisliği

Bölümü, Kanuni Kampusü Trabzon, Türkiye

$\triangle:$ aytac@ktu.edu.tr

Cep telefonu : $+90(505) 2319178$

Telefon : $+90(462) 3771513$

Faks : $\quad+90(462) 3257499$

\section{nda Yapı Malze mesi Seçimi ve Tas arım Stilinin Fırın Isıl} Özellikle rine Etkisinin İncele nmesi

Öz: Kereste kurutmada yoğun enerji tüketiminin maliy etlere ve çevre kirliliğine olumsuz etkileri son yıllarda güneş enerjisinden yararlanma eğilimini güçlendirmiştir. Düz toplayıcılı güneş firınlarında kerestenin kurutulması klasik kurutmaya oranla fazla zaman almasına rağmen enerji maliy etleri düşük ve olumsuz çevresel etkileri yoktur. Bu çalışmada güneş firınlarının tasarımında kullanılacak yap1 malzemelerinin ve tasarım şeklinin seçimi isıl özellikler bakımından değerlendirilmiştir. Farklı 1sıl kapasiteye sahip malzemeler farklı tasarım şeklinde farklı isıl özellik oluşturmaktadır. Dolayısıyla, farklı yapı malzemesi ve tasarım şekli seçimi ile güneş enerjili kereste kurutma firınında gün boyu sıcaklık dağılımının gidişinin kontrolü mümkün olabilmektedir.

Anahtar kelimeler: Günes fırınları, kurutma, termal özellikler, yapı malzemesi.

\section{INTRODUCTION}

Natural and technical drying methods are generally used in drying timber. Although energy is not consumed in natural drying, the drying period is long and timber cannot be dried to the desired result humidity for interiors. Although the timber can be dried to the desired result humidity level in technical drying, drying costs are high. $60-70 \%$ of the energy in the timber industry is spent during the drying phase. The energy consumed depending on the tree type and timber thickness varies between 600$1000 \mathrm{kWh}$ per $1 \mathrm{~m}^{3}$ of timber (Comstock, 1978).

In recent years, drying timber with solar energy has been studied as an alternative drying method in order 
to reduce energy costs in drying. For this purpose, various types of solar-powered timber drying furnaces are designed and drying trials are carried out. In most of these studies, it has been concluded that solar furnaces can be used economically if the fuel prices increase and the costs of solar collectors can be reduced. In these studies, little coverage has been given to the effects of wall building materials on the temperature regime (Read et al.,1974; Gaugh, 1977; Bois, 1977; Yang,1980; Chen, 1981; Little,1984; Örs and Üçüncü,1992).

In terms of drying quality, drying temperatures suitable for the properties of the dried timber should be applied. In solar furnaces, the temperature varies according to solar energy values and shows significant differences throughout the day. During the sunbathing period, the temperature first rises and decreases again after reaching the maximum value between 12:00 - 14:00. The width of the hourly temperature change interval negatively affects the drying time and quality. In Figure 1, possible hourly variations in temperature during the day are shown for a solar furnace. The temperature of the furnace, which decreases to the lowest level at night, reaches its maximu $\mathrm{m}$ value between 13:00 and 14:00 during the day due to the effect of solar radiation, and this temperature difference between this temperature difference negatively affects the drying.

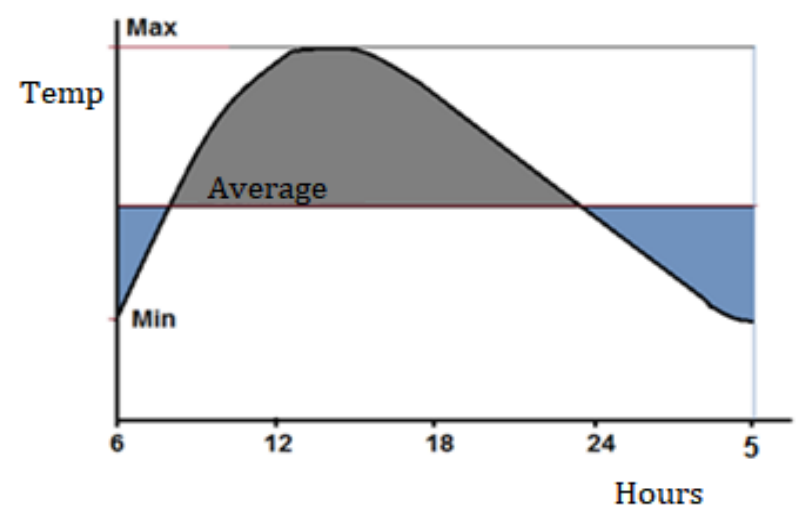

Figure 1. Hourly change graph of temperature in solar furnace.

The specific heat and heat conduction coefficients of the wall materials also have an important effect on the change of furnace temperature. Therefore, by choosing the wall building materials to be used, a more homogeneous distribution of the oven temperature can be achieved. Greenhouse type solar furnaces have been considered in this study and these furnaces can be designed up to $10 \mathrm{~m}^{3}$ capacity. In the study, the effects of the wall designs of the greenhouse type solar furnace with a lumber capacity of 10 $\mathrm{m}^{3}$ and a collector area of $60 \mathrm{~m}^{2}$ on the temperature regime were examined.

\section{MATERIALS AND METHOD}

Materials: The collector area of the examined greenhouse type solar furnace is $60 \mathrm{~m}^{2}$ and its timber capacity is $10 \mathrm{~m}^{3} .34 .5 \mathrm{~m}^{2}$ of the solar collector designed in the position of the roof of the oven has a $30^{\circ}$ and $25.5 \mathrm{~m}^{2}$ slope of $60^{\circ}$ (Üçüncü,1995).

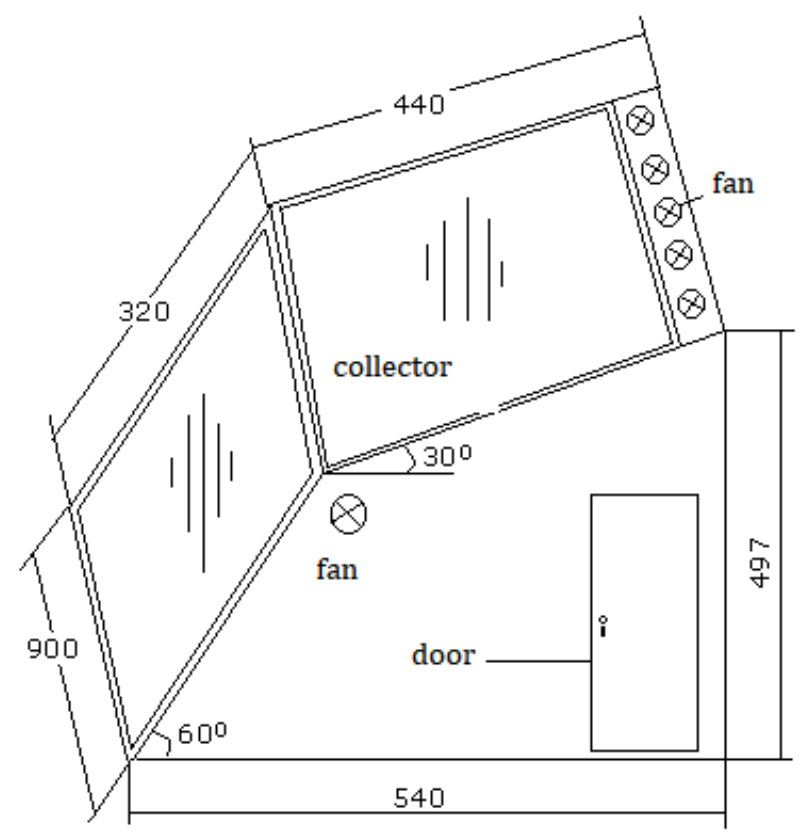

Figure 2. Solar furnace.

In order to examine the effects of wall designs and materials on temperature regime, 4 types of walls were designed (Figure 3).

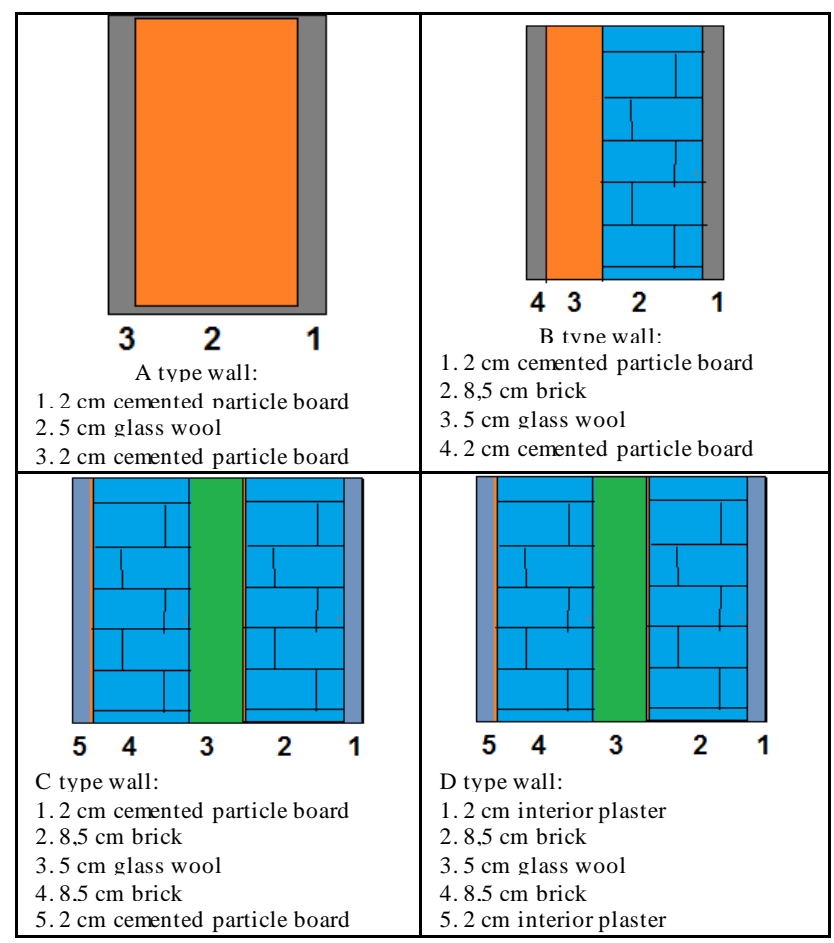

Figure 3. Wall design and building materials 
Method: The furnace temperature was calculated using the thermal equilibrium equation (Dağsöz,1977).

$Q g=Q d+Q k$

Here, Qg is the useful solar radiation (W) entering the furnace, Qd is the energy stored in the furnace walls (W), Qk is the heat lost from the furnace (W).

Useful solar radiation entering the oven

$Q g=\eta$ Ac Ie

Here, $\eta$ is collector efficiency, Ac collector field and $\mathrm{Ie}$ is the instantaneous solar radiation incident on the collector surface. Hourly solar radiation values coming to the collector surface are calculated from Trabzon's average irradiance values for many years and given in Table 1 (Kılıç and Öztürk,1983). The value of $45 \%$ was taken as a basis for collector efficiency (Üçüncü,1991).

Stored heat

$Q d=\sum m C p\left(t_{i}-t_{i-1}\right)$

Lost heat

$$
Q k=K A d\left(t_{i}-t_{o}\right)
$$

Table 1. Hourly solar radiation coming to the collector surface in Trabzon and monthly average values of outdoor temperature, Ie $\left(\mathrm{W} / \mathrm{m}^{2}\right)$.

\begin{tabular}{|c|c|c|c|c|c|c|c|c|c|c|c|c|c|c|c|c|c|c|c|c|c|c|c|c|c|c|}
\hline \multirow{2}{*}{ Months } & \multicolumn{24}{|c|}{ Hours } & \multirow{2}{*}{ Total } & \multirow{2}{*}{$\begin{array}{c}\text { Tempreture } \\
\left({ }^{\circ} \mathrm{C}\right)\end{array}$} \\
\hline & 6 & 7 & 8 & 9 & 10 & 11 & 12 & 13 & 14 & 15 & 16 & 17 & 18 & 19 & 20 & 21 & 22 & 23 & 24 & 1 & 2 & 3 & 4 & 5 & & \\
\hline January & 0 & 8 & 112 & 232 & 310 & 344 & 344 & 310 & 232 & 112 & 8 & 0 & 0 & 0 & 0 & 0 & 0 & 0 & 0 & 0 & 0 & 0 & 0 & 0 & 2012 & 7,4 \\
\hline February & 0 & 58 & 191 & 315 & 397 & 436 & 436 & 397 & 315 & 191 & 58 & 0 & 0 & 0 & 0 & 0 & 0 & 0 & 0 & 0 & 0 & 0 & 0 & 0 & 2794 & 7,3 \\
\hline March & 21 & 116 & 234 & 336 & 407 & 437 & 437 & 407 & 336 & 234 & 116 & 21 & 0 & 0 & 0 & 0 & 0 & 0 & 0 & 0 & 0 & 0 & 0 & 0 & 3102 & 8,3 \\
\hline April & 69 & 177 & 298 & 400 & 463 & 493 & 493 & 463 & 400 & 298 & 177 & 69 & 0 & 0 & 0 & 0 & 0 & 0 & 0 & 0 & 0 & 0 & 0 & 0 & 3800 & 11,4 \\
\hline May & 102 & 216 & 334 & 424 & 487 & 517 & 517 & 487 & 424 & 334 & 216 & 102 & 0 & 0 & 0 & 0 & 0 & 0 & 0 & 0 & 0 & 0 & 0 & 0 & 4160 & 15,8 \\
\hline June & 119 & 242 & 335 & 447 & 506 & 539 & 539 & 506 & 447 & 335 & 242 & 119 & 0 & 0 & 0 & 0 & 0 & 0 & 0 & 0 & 0 & 0 & 0 & 0 & 4376 & 20,0 \\
\hline July & 100 & 213 & 320 & 401 & 457 & 482 & 482 & 457 & 401 & 320 & 213 & 100 & 0 & 0 & 0 & 0 & 0 & 0 & 0 & 0 & 0 & 0 & 0 & 0 & 3946 & 22,6 \\
\hline September & 36 & 135 & 249 & 345 & 406 & 441 & 441 & 406 & 345 & 249 & 135 & 36 & 0 & 0 & 0 & 0 & 0 & 0 & 0 & 0 & 0 & 0 & 0 & 0 & 3224 & 20,0 \\
\hline October & 0 & 79 & 212 & 324 & 401 & 436 & 436 & 401 & 324 & 212 & 79 & 0 & 0 & 0 & 0 & 0 & 0 & 0 & 0 & 0 & 0 & 0 & 0 & 0 & 2904 & 16,5 \\
\hline November & 0 & 19 & 151 & 273 & 362 & 396 & 396 & 362 & 273 & 151 & 19 & 0 & 0 & 0 & 0 & 0 & 0 & 0 & 0 & 0 & 0 & 0 & 0 & 0 & 2402 & 13,2 \\
\hline December & 0 & 3 & 90 & 211 & 288 & 322 & 322 & 288 & 211 & 90 & 3 & 0 & 0 & 0 & 0 & 0 & 0 & 0 & 0 & 0 & 0 & 0 & 0 & 0 & 1828 & 9,7 \\
\hline Average & 52 & 138 & 251 & 353 & 421 & 452 & 452 & 421 & 353 & 251 & 138 & 52 & 0 & 0 & 0 & 0 & 0 & 0 & 0 & 0 & 0 & 0 & 0 & 0 & 3334 & 16,1 \\
\hline
\end{tabular}

Here, $\mathrm{m}$ wall mass $(\mathrm{kg})$, specific heat of $\mathrm{Cp}$ wall material $\left(\mathrm{Wh} / \mathrm{kg}{ }^{\circ} \mathrm{C}\right), \sum \mathrm{mCp}$ sum of thermal capacities of furnace walls $\left(\mathrm{WH} /{ }^{\circ} \mathrm{C}\right)$, furnace temperature at ti $\mathrm{i}\left({ }^{\circ} \mathrm{C}\right), \mathrm{t}_{\mathrm{i}-1}$ initial furnace temperature $\left({ }^{\circ} \mathrm{C}\right)$, to outdoor temperature $\left({ }^{\circ} \mathrm{C}\right), \mathrm{K}$ is the total heat transfer coefficient of the furnace $\left(\mathrm{W} / \mathrm{m}^{2}{ }^{\circ} \mathrm{C}\right)$, Ad is the furnace wall area $\left(\mathrm{m}^{2}\right)$. Based on the equations given, the following equation is obtained for the oven temperature.

$$
t_{i}=\frac{\eta A c I e+\sum m C p t_{i-1}+K A d t_{o}}{\sum m C p+K A d}
$$

In the calculation of the total heat transfer coefficient, the heat transfer coefficient of the wall and the heat losses resulting from air renewal are taken into account. The furnace volume is approximately $150 \mathrm{~m}^{3}$ and the rate of air regeneration in the furnace has been taken as 4 , considering the required moist air requirement for drying. Equations and equation coefficients regarding the possible temperatures that will occur in the furnace according to the designed walls are given below.

For wall type A:

$t_{i}=0,0250$ Ie $+0,7868 t_{i-1}+0,2132 t_{o}$

For wall type B:

$t_{i}=0,0175 \mathrm{Ie}+0,8366 t_{i-1}+0,1634 t_{o}$

$$
\begin{aligned}
& \text { For type } \mathrm{C} \text { wall: } \\
& t_{i}=0,0118 \mathrm{Ie}+0,9026 t_{i-1}+0,0974 t_{o} \\
& \text { For wall type } \mathrm{D} \text { : } \\
& t_{i}=0,0153 \mathrm{Ie}+0,8740 t_{i-1}+0,1260 t_{o}
\end{aligned}
$$

\section{FINDINGS}

The temperature in solar furnaces varies significantly throughout the day due to reasons such as the constant change of solar energy during the day, the variation in terms of the seasons, and none at night. With these features, drying in solar ovens can be considered within the concept of batch drying. Although intermittent drying does not have a direct harmful effect on drying quality, the continuous and sudden change in temperature may affect the drying quality as well as increase the drying time. Wall materials also have a significant effect on the furnace temperature in solar furnaces. In order to examine the effect of wall materials on temperature, the annual average hourly temperature distribution, standard deviation, maximum, minimum and change interval values for four types of furnace walls designed in Trabzon climatic conditions are given in Table 2. 
Table 2. Furnace temperature values according to wall types.

\begin{tabular}{cccccccccccccccccccccccccccccccc}
\hline $\begin{array}{l}\text { Wall } \\
\text { type }\end{array}$ & $\mathbf{6}$ & $\mathbf{7}$ & $\mathbf{8}$ & $\mathbf{9}$ & $\mathbf{1 0}$ & $\mathbf{1 1}$ & $\mathbf{1 2}$ & $\mathbf{1 3}$ & $\mathbf{1 4}$ & $\mathbf{1 5}$ & $\mathbf{1 6}$ & $\mathbf{1 7}$ & $\mathbf{1 8}$ & $\mathbf{1 9}$ & $\mathbf{2 0}$ & $\mathbf{2 1}$ & $\mathbf{2 2}$ & $\mathbf{2 3}$ & $\mathbf{2 4}$ & $\mathbf{1}$ & $\mathbf{2}$ & $\mathbf{3}$ & $\mathbf{4}$ & $\mathbf{5}$ & t1 & S1 & MAX & Mİ & CI \\
\hline $\mathrm{A}$ & 16 & 18 & 24 & 30 & 37 & 43 & 48 & 51 & 52 & 50 & 45 & 40 & 35 & 30 & 27 & 24 & 22 & 21 & 19 & 18 & 18 & 17 & 16 & 16 & 30 & 13 & 52 & 16 & 36 \\
$\mathrm{~B}$ & 15 & 17 & 21 & 26 & 31 & 36 & 40 & 43 & 45 & 44 & 41 & 38 & 34 & 31 & 28 & 26 & 24 & 22 & 21 & 20 & 19 & 18 & 18 & 17 & 28 & 11 & 45 & 15 & 29 \\
$\mathrm{C}$ & 15 & 16 & 19 & 23 & 27 & 31 & 34 & 37 & 39 & 39 & 38 & 37 & 35 & 33 & 31 & 29 & 28 & 27 & 25 & 24 & 23 & 23 & 22 & 21 & 28 & 9 & 39 & 15 & 24 \\
$\mathrm{D}$ & 15 & 17 & 20 & 25 & 30 & 35 & 39 & 42 & 44 & 44 & 42 & 39 & 36 & 33 & 31 & 29 & 27 & 26 & 24 & 23 & 22 & 21 & 20 & 20 & 29 & 11 & 45 & 15 & 29 \\
\hline
\end{tabular}

In Table 3, the monthly average furnace temperature and standard deviation values for four types of furnace walls. Here, $\mathrm{t} 1$ and $\mathrm{S} 1$ are solar furnace temperature $\left({ }^{\circ} \mathrm{C}\right)$ and standard deviation with wall type $\mathrm{A}$, $\mathrm{t} 2$ and $\mathrm{S} 2$ solar furnace temperature and standard deviation with wall type $\mathrm{B}, \mathrm{t} 3$ and $\mathrm{S} 3$ solar furnace temperature and standard deviation with wall type C, $\mathrm{t} 4$ and S4 D-type wall furnace temperature and standard deviation.

Table 3. Monthly average temperature and standard deviation values of furnace types.

\begin{tabular}{|c|c|c|c|c|c|c|c|c|}
\hline \multirow{2}{*}{ Months } & \multicolumn{2}{|c|}{$\mathbf{A}$} & \multicolumn{2}{|c|}{ B } & \multicolumn{2}{|c|}{$\mathbf{C}$} & \multicolumn{2}{|c|}{ D } \\
\hline & t1 & S1 & t1 & S1 & t1 & S1 & t1 & S1 \\
\hline January & 17,1 & 9,2 & 16,0 & 6,9 & 16,0 & 5,2 & 16,8 & 6,5 \\
\hline February & 20,8 & 12,1 & 19,3 & 9,2 & 19,2 & 6,9 & 20,3 & 8,5 \\
\hline March & 23,2 & 12,7 & 21,6 & 9,6 & 21,5 & 7,2 & 22,7 & 9,0 \\
\hline April & 29,7 & 14,8 & 27,7 & 11,2 & 27,6 & 8,4 & 29,1 & 10,5 \\
\hline May & 35,8 & 15,7 & 33,6 & 12,0 & 33,5 & 9,0 & 35,2 & 11,2 \\
\hline June & 41,1 & 16,4 & 38,7 & 12,5 & 38,6 & 9,3 & 40,4 & 11,6 \\
\hline July & 41,6 & 14,8 & 39,5 & 11,3 & 39,4 & 8,4 & 41,1 & 10,5 \\
\hline August & 40,4 & 13,8 & 38,5 & 10,5 & 38,4 & 7,8 & 40,0 & 9,8 \\
\hline September & 35,5 & 12,9 & 33,8 & 9,8 & 33,7 & 7,3 & 35,1 & 9,2 \\
\hline October & 30,5 & 12,4 & 28,9 & 9,4 & 28,9 & 7,0 & 30,1 & 8,8 \\
\hline November & 24,8 & 10,8 & 23,5 & 8,2 & 23,5 & 6,1 & 24,5 & 7,6 \\
\hline December & 18,5 & 8,5 & 17,5 & 6,4 & 17,5 & 4,8 & 18,3 & 6,0 \\
\hline Average & 29,9 & 12,8 & 28,2 & 9,7 & 28,2 & 7,3 & 29,5 & 9,1 \\
\hline
\end{tabular}

Average oven temperature has the highest value in A type oven and the lowest in C type oven. In A type oven, the highest value of the average oven temperature during the day (24 hours) occurred in July with $41.6{ }^{\circ} \mathrm{C}$, and the lowest value occurred in January with $17.1{ }^{\circ} \mathrm{C}$. The same values in $\mathrm{B}, \mathrm{C}$ and $\mathrm{D}$ type furnaces, respectively; 39.5; 39.4; $40.1{ }^{\circ} \mathrm{C}$ and $16.0 ; 16.0$; It became $16.8{ }^{\circ} \mathrm{C}$. Standard deviation also increases in high temperature average values. The largest standard deviation was observed in A type furnace with $12.8{ }^{\circ} \mathrm{C}$, the smallest standard deviation was observed in $\mathrm{C}$ type furnace with 7.3

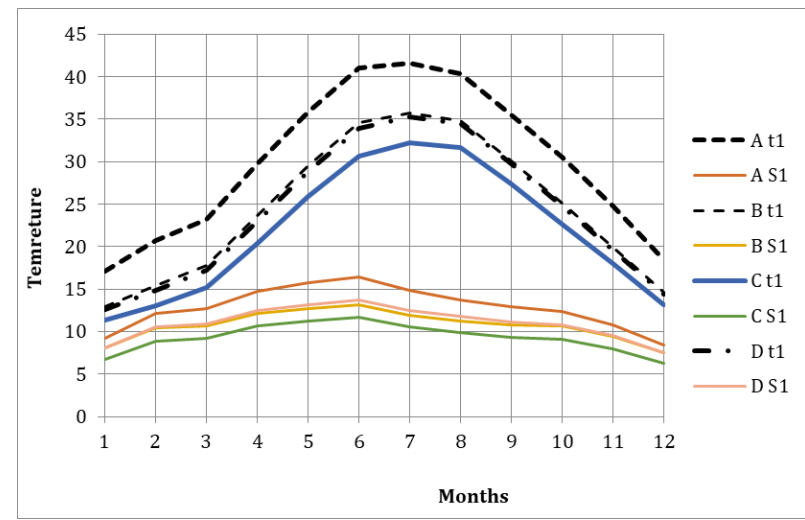

Figure 4. Monthly average temperatures.
${ }^{\circ} \mathrm{C}$. In Figure 4, the temperature changes of solar furnaces with wall types $\mathrm{A}, \mathrm{B}, \mathrm{C}$ and $\mathrm{D}$ are shown by months depending on time. In Figure 5, hourly temperature distribution for wall types is shown. In solar furnaces, the maximum temperature for any type of wall material is generally reached between 14:00 and 15:00 hours. In the solar oven for all wall types, the temperature of the oven does not fall to the ambient temperature the next day, when the solar radiation starts. In the furnace with a wall with a high thermal capacity, the difference between the final temperature and the ambient temperature is greater.

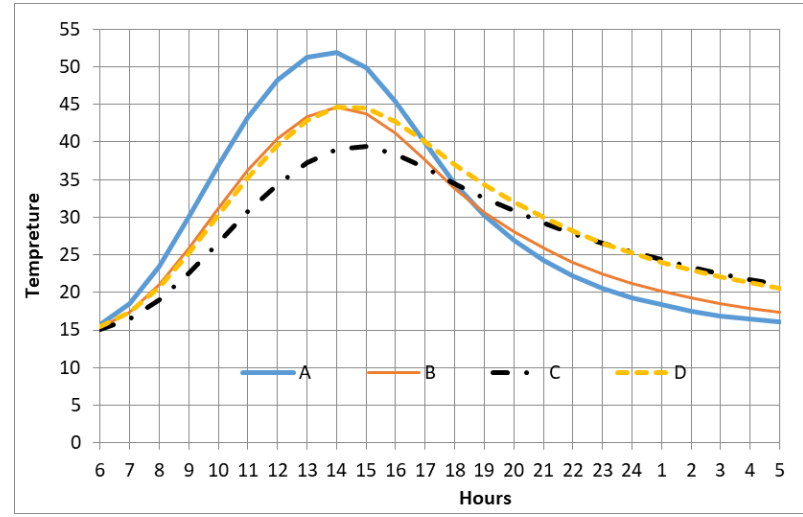

Figure 5. Hourly temperature distribution according to wall types. 


\section{DISCUSSION AND CONCLUSION}

Since materials with high thermal capacity will store large amounts of heat, the furnace temperature decreases in furnaces built of these materials. However, despite the low temperatures that occur in the oven during the sunbathing period, the temperature drop is less after the sunbathing ends and at night. In furnaces built of materials with low thermal capacity, the temperature of the furnace, which is higher during the sunbathing period, is greater at night. Accordingly, although the average temperature is lower in furnaces built with materials with high thermal capacity, the variation interval and standard deviation are also small, so they may have more positive effects on the drying quality. This type of furnace has more suitable features in terms of ensuring homogeneous and high quality drying.

In solar systems where high temperatures are desired during the sunshine period, the selection of low thermal capacity building materials can be recommended. However, it would be beneficial to use materials with higher thermal capacity in solar ovens where activity is desired throughout the day. According to theoretical calculations, it is seen that more stable temperature values will be formed in solar furnaces to be built from $\mathrm{C}$ and $\mathrm{D}$ type walls.

In terms of heat loss in solar furnaces, since the heat losses caused by air renewal are more effective than the thermal conductivity of wall materials, the thermal insulation thickness of $5 \mathrm{~cm}$ is taken as a basis instead of the $8 \mathrm{~cm}$ thermal insulation thickness recommended in the literature. For the same reason, it is possible to use polyurethane or styrofoam for thermal insulation.

\section{ACKNOWLEDGMENTS}

This study was presented in ORENKO 2020 held by Karadeniz Technical University, Trabzon.

\section{REFERENCES}

Bois,P.J. (1977). Construction and operating, a small solar heated lumber dryer. Forest Products Utilization Technical Report. USDA, For. Service No. 7. 11 pp.

Chen, P.Y.S. (1981). Design and tests of a 500 BF solar kiln. Forest Prod. J., 31(3), 33-38.

Comstock, G.L. (1978). Energy requirement for drying of wood products. Forest Prod. J., 28(3), 22-26.

Dağsöz, A.K. (1977). Heat transfer. ITU Faculty of Mechanical Engineering, İstanbul.

Gaugh, D.K. (1977). The design and operating a small solar timber kiln. Fiji Timbers and Their Uses, No: 67, Fiji, F. D., 17pp.
Kılıç, A. \& Öztürk, A. (1983). Solar energy. ITU Faculty of Mechanical Engineering, İstanbul.

Little, R.L. (1984). Industrial use of solar heat in lumber drying: a long-term performance report. Forest Prod. J., 34(9), 22-26.

Örs, Y. \& Üçüncü, K. (1992). Investigations on lumber drying possibilities at $41^{\circ}$ north parallel. TÜBITAK Nature Magazine, 16, 22-37.

Read, W. R., Choda, A. \& Cooper, P. I. (1974). A Solar timber kiln. Solar Energy. 15(4), 309-316.

Üçüncü, K. (1991). Investigation ofdrying possibilities of timber (eastern spruce) with solar energy in $41^{\circ}$ north latitude (Trabzon). $\mathrm{PhD}$ Thes is (Unpublished), KTU Institute of Science and Technology, Trabzon.

Üçüncü, K. (1995). Greenhouse type solar furnace design and economic analysis for small capacity timber cutting and furniture plants in the climatic conditions of the Black Sea Region. I. National Black Sea Forestry Congress, 2. Volume, Proceedings, Trabzon.

Yang, K.L. (1980). Solar kiln performance at a high latitude, $48^{\circ}$ N. Forest Prod., 30(3), 37-40. 